\title{
ANALISIS KECEPATAN ARUS UNTUK PENENTUAN LOKASI PEMBANGUNAN MARINE CURRENT TURBINE DI PANTAI SELATAN JAWA
}

\author{
Danar Guruh Pratomo*1, Lilik Widiastuti ${ }^{2}$ \\ 1,2Departemen Teknik Geomatika, FTSLK-ITS, Kampus ITS Sukolilo, Surabaya, 60111, Indonesia \\ e-mail: *1 guruh@geodesy.its.ac.id
}

\begin{abstract}
Abstrak
Energi pembangkit fosil merupakan faktor terbesar terjadinya kerusakan lingkungan yang menyebabkan terjadinya pemanasan global, hujan asam, dan perubahan iklim. Selain itu, energi fosil yang semakin menipis dan tidak dapat diperbarui kembali mendorong penggunaan energi terbarukan yang dirasa lebih efisien dan tidak merusak lingkungan. Salah satu energi terbarukan yang sedang dikembangkan oleh beberapa negara maju yakni energi kelautan yang berasal dari pengaruh fenomena pasang surut air laut. Keuntungannya adalah dapat diprediksikan berdasarkan waktu dan karakter pasang surut yang terjadi di suatu tempat. Lokasi penelitian berada di Pantai Selatan Jawa yang memiliki kecepatan arus yang cukup tinggi karena berbatasan langsung dengan Samudera Hindia. Pada penelitian ini dilakukan dengan melakukan pemodelan numerik terhadap aliran fluida 3D yang menghasilkan kecepatan arus dan digunakan untuk penentuan lokasi pembangunan MCT. Pemodelan dilakukan dengan menggunakan beberapa parameter seperti data batimetri, data garis pantai, data pasang, serta data kecepatan arus geostropik dari satelit altimetri. Waktu pemodelan didasarkan pada data curah hujan tahun 2016. Untuk perhitungan estimasi energi yang dihasilkan menggunakan parameter MCT yang memiliki diameter $16 \mathrm{~m}, 18 \mathrm{~m}$ dan $20 \mathrm{~m}$, kedalaman 30 sampai dengan $40 \mathrm{~m}$ serta kecepatan arus minimum $1,5 \mathrm{~m} / \mathrm{s}$. Dari hasil pemodelan didapatkan, terdapat 124 titik lokasi pembangunan MCT yang memiliki estimasi energi per bulan sebesar 166,900 MWh pada bulan Maret yang mewakili curah hujan teredah dan 159,416 MWh pada bulan Oktober yang mewakili curah hujan tertinggi.
\end{abstract}

Kata kunci : Kecepatan Arus, MCT, Model Hidrodrodinamika, Pesisir Selatan Jawa

\begin{abstract}
Fossil-generating energy is the biggest factor of environmental damage which causes global warming, acid rain, and climate change. In addition, the decreasing of non-renewable fossil energy encourages the use of renewable energy that is perceived to be more efficient and environmentally friendly. One renewable energy which is being developed is marine energy. This source of energy is mainly derived from the tide. The advantage is that it can be predicted based on the time and tidal characters. The research is located on the Southern Coast of Java which has a high current velocity because it is directly adjacent to the Indian Ocean. The research employed 3D numerical modeling of fluid flow which simulates current velocities of the research area. The models then were used to determine the possible location of MCT. Several parameters were used to build the models, such as bathymetry data, coastline data, and tidal data. In order to validate the models, the current magnitude of the model is compared with magnitude of geostrophic current which is derived from altimetry satellite. The research used several scenarios of the rotor dimension $116 \mathrm{~m}$, a $18 \mathrm{~m}$, and $20 \mathrm{~m}$ ) to estimate the energy resulted from MCT. Rotors were assumed located in the depth of $30 \mathrm{~m}$ to $40 \mathrm{~m}$ and the minimum current velocity $1.5 \mathrm{~m} / \mathrm{s}$ to move the rotors. The results showed there are 124 points of MCT development sites which have an estimated energy per month of 166,900 MWh in March and 159,416 MWh in October.
\end{abstract}

Keywords : Current Magnitude, MCT, Hydrodynamic Model, Southern Java Coast

\section{PENDAHULUAN}

Energi listrik merupakan alat penunjang aspek kehidupan dan pembangunan nasional dalam peningkatan mutu taraf hidup bangsa Indonesia.
Penggunaan energi listrik pembangkit fosil dirasa sudah tidak ekonomis lagi dikarenakan persediaannya yang sudah semakin menipis sehingga dibutuhkan alternatif lain sebagai tenaga pembangkit listrik. Berdasarkan Peraturan Presiden 
Nomor 5 Tahun 2006 tentang Kebijakan Energi Nasional bahwa negara menjamin pasokan energi dalam negeri dan untuk pembangunan yang berkelanjutan.

Salah satu langkah kebijakan Kementerian Energi dan Sumber Daya Mineral (KESDM) dalam menjawab isu nasional mengenai energi dengan diversifikasi energi adalah penganekaragaman penyediaan dan pemanfaatan berbagai sumber energi baru, salah satunya adalah sumber energi kelautan (ESDM, 2005). Dasar pengembangan kelautan telah diatur dalam Undang Undang Nomor 17 Tahun 2007 tentang Rencana Jangka Panjang Nasional (RPJPN). Kenyataannya, rencana ini masih belum dapat terealisasikan karena beberapa hal, diantaranya belum tersedianya informasi potensi energi kelautan yang secara ekonomis dapat dimanfaatkan untuk pembangkit tenaga listrik.

Dengan kondisi topografi Indonesia yang merupakan negara kepulauan terbesar dengan total luas lautan hampir 8 juta $\mathrm{km}^{2}$ serta memiliki panjang garis pantai kurang lebih sekitar 81.000 $\mathrm{km}$. Indonesia memiliki potensi yang sangat besar terhadap pengembangan energi arus dan pasang surut air laut dalam pembangunan energi terbarukan sebagai upaya penting dalam mengeksplorasi sumber energi non konvensional dari laut.

Penelitian ini dimaksudkan untuk mengetahui lokasi dengan tingkat kesesuaian arus pasang surut air laut yang baik dalam pembangunan MCT dengan pemodelan numerik tiga dimensi. Keuntungan energi pasang surut air laut adalah dapat diprediksi karena perubahan energi arus pasang surut dapat ditentukan berdasarkan jarak suatu lokasi pada permukaan bumi terhadap posisi bulan dan matahari.

Menurut Lubis (2006) Pantai Selatan Jawa memiliki kondisi pasang surut dengan tipe campuran dominan semidurnal. Selain itu, Pantai Selatan Jawa memiliki gelombang dan arus besar karena wilayahnya berbatasan langsung dengan Samudera Hindia. Pemanfaatan energi arus pasang surut diharapkan dapat di implementasikan dengan baik di Indonesia selain hemat dalam perawatan, energi arus pasang surut juga meminimalisir kerusakan lingkungan dibandingkan penggunaan energi fosil.

\section{METODE}

Penelitian ini menggunakan pendekatan pemodelan hidrodinamika tiga dimensi untuk melakukan analisis kecepatan arus yang memiliki potensi untuk lokasi MCT. Model hidrodinamika yang dibangun pada penelitian ini menggunakan data batimetri, data garis pantai, dan data pengamatan dan prediksi pasang surut air laut. Sebagai model validator, digunakan arus geostropik yang diturunkan dari data satelit altimetri. Kecepatan arus diperoleh dari komponen barat-timur $(u)$ dan komponen selatan-utara $(v)$. Nilai resultan kecepatan arus dihitung dengan menggunakan persamaan:

$$
R=\sqrt{u^{2}+v^{2}}
$$

Model hidrodinamika yang dibangun menggunakan mesh berbentuk TIN (Triangular Irregular Network). TIN lebih responsif terhadap geomorfologis dari garis pantai dan kedalaman perairan yang variatif. Gambar 1 menunjukkan batas wilayah penelitian yang berada pada koordinat $6^{\circ} 45^{\prime} 20,08^{\prime \prime}$ - $10^{\circ} 52^{\prime} 8,95^{\prime \prime}$ LS dan $104^{\circ} 33,28^{\prime \prime}-114^{\circ} 38^{\prime} 40,39^{\prime \prime}$ BT.

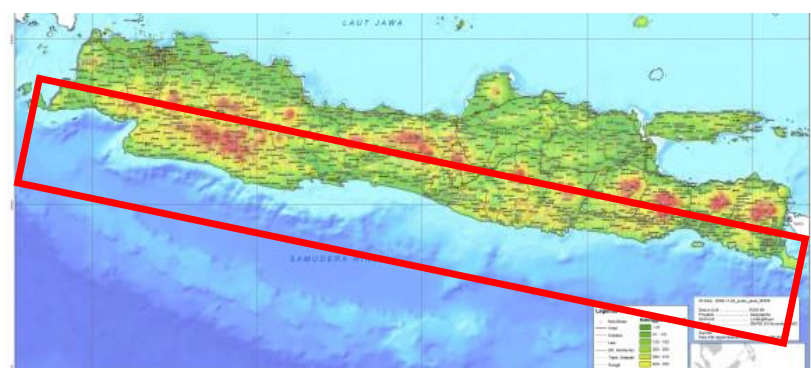

Gambar 1. Lokasi Penelitian

Parameter yang digunakan untuk membuat mesh adalah sudut minimum mesh $30^{\circ}$, luas mesh minimum $0,002^{\circ}$, dan jumlah iterasi 30 kali. Untuk proses editing mesh, digunakan untuk penentuan batas area penelitian (boundary condition). Pada penelitian ini, bagian utara menggunakan batas darat dengan 8 lokasi pengamatan pasut dan 3 titik pasut prediksi di sepanjang garis pantai. Sedangkan untuk batas area bagian selatan yang berbatasan langsung dengan perairan bebas menggunakan 5 titik pasut prediksi. 
Proses pemodelan arus secara tiga dimensi dilakukan pada dua skenario yang berbeda. Skenario yang pertama, pemodelan dilakukan pada bulan Maret dimana pada bulan tersebut memiliki curah hujan terendah dibanding bulanbulan yang lain. Skenario kedua, dilakukan pada bulan Oktober ketika curah hujan tertinggi.

Pemodelan dilakukan selama 19 hari dengan waktu pemanasan (warming up time) model selama 3,5 hari dan percepatan waktu putar (spin up time) model selama 0,5 hari sebelum model dijalankan selama 15 hari. Interval waktu perekaman (time step) dari model dilakukan setiap 3600 detik untuk model hidrodinamika bulan Maret dan Oktober 2016.

Kecepatan arus MCT menambahkan parameter struktur turbin dengan memasukkan data kedalaman antara $30 \mathrm{~m}$ sampai dengan $40 \mathrm{~m}$, posisi kedalaman rotor diletakkan (centroid). Penelitian ini menggunakan scenario ukuran rotor turbin MCT dengan diameter $16 \mathrm{~m}, 18 \mathrm{~m}$, dan 20m. Selanjutnya, untuk estimasi energi yang dihasilkan oleh MCT dihitung dengan menggunakan persamaan rumus (2) dengan berikut:

$$
P=C_{\mathrm{p}} \cdot A \cdot v^{\mathrm{a}}
$$

Dimana :

$P$ = daya (Watt)

$C_{\mathrm{p}}=$ koefisien daya

$A=$ luas area sapuan rotor $\left(\mathrm{m}^{2}\right)$

$v=$ kecepatan arus $(\mathrm{m} / \mathrm{s})$

\section{HASIL DAN PEMBAHASAN}

\section{Pemodelan Arus di Pantai Selatan Jawa}

Pemodalan hidrodinamika tiga dimensi diawali dengan pembuatan mesh yang terdapat dalam model domain. Pembuatan mesh dan editing mesh merupakan tahap utama dalam pemodelan karena semakin baik bentuk mesh akan menghasilkan model yang baik dan akan merepresentasikan keadaan yang sebenarnya.

Proses yang terdapat dalam pengeditan mesh diantaranya adalah pemindahan titik, merging triangular elements, dan penghalusan batasbatas daratan lautan. Gambar 2 merupakan hasil pengeditan mesh yang digunakan untuk membangun model hidrodinamika tiga dimensi pada penelitian ini. Jumlah elemen yang terdapat dalam model domain adalah 7708 elemen dan jumlah titik yang menyusun mesh adalah 12125 titik.

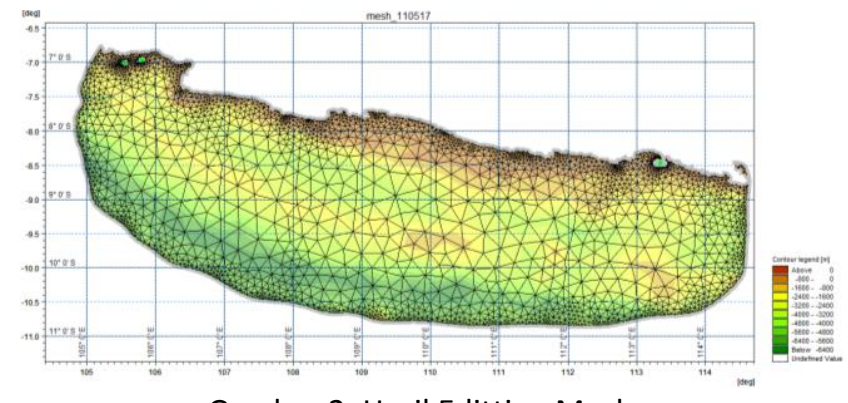

Gambar 2. Hasil Editting Mesh

Analisa kecepatan arus dilakukan dalam beberapa skenario yaitu pada saat kondisi pasang dan kondisi surut di bulan Maret dan bulan Oktober 2016. Pada bulan Maret kondisi pasang tertinggi terjadi pada tanggal 12 pukul 09:00 WIB. Pada saat kondisi pasang tertinggi, kecepatan arus maksimum sebesar $5.881 \mathrm{~m} / \mathrm{s}$ dan arah arus cenderung menuju daratan.

Pada bulan Maret, kondisi surut terendah terjadi pada tanggal 12 pukul 16:00 WIB dengan kecepatan arus maksimum sebesar $5,812 \mathrm{~m} / \mathrm{s}$, dan arah arus cenderung menjauhi daratan. Pola kecepatan arus pada saat pasang tertinggi dan surut terendah dapat dilihat pada Gambar 3 dan 4.

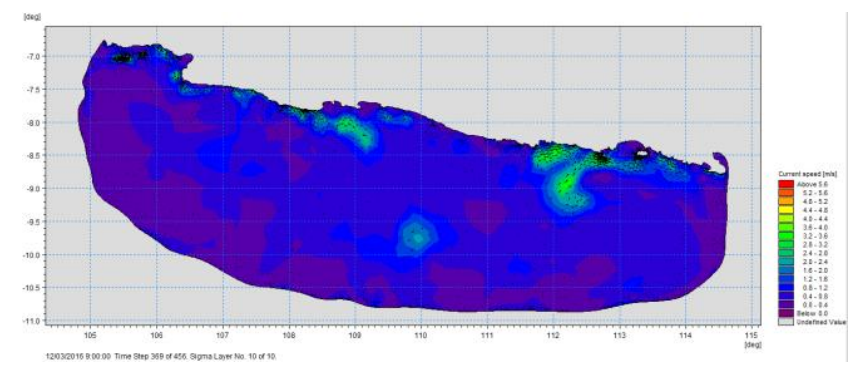

Gambar 3. Pola Arus Area Penelitian Saat Pasang Tertinggi Pada Bulan Maret 2016

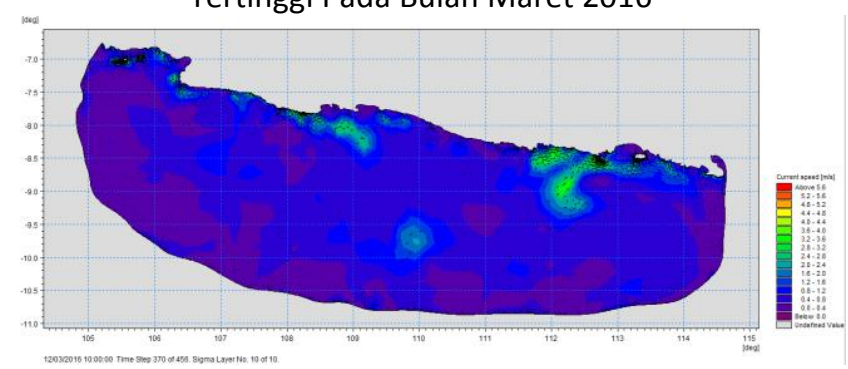

Gambar 4. Pola Arus Area Penelitian Saat Surut Terendah Pada Bulan Maret 2016 
Pada bulan Oktober kondisi pasang tertinggi terjadi pada tanggal 4 pukul 18:00 WIB. Pada saat kondisi pasang tertinggi, kecepatan arus maksimum sebesar $5,679 \mathrm{~m} / \mathrm{s}$ dan arah arus cenderung menuju daratan. Sedangkan saat kondisi surut terendah terjadi pada tanggal 4 pukul 11:00 WIB dengan kecepatan arus maksimum sebesar $6,374 \mathrm{~m} / \mathrm{s}$, dan arah arus cenderung menjauhi daratan. Pola kecepatan arus pada saat pasang tertinggi dan surut terendah dapat dilihat pada Gambar 5 dan 6 .

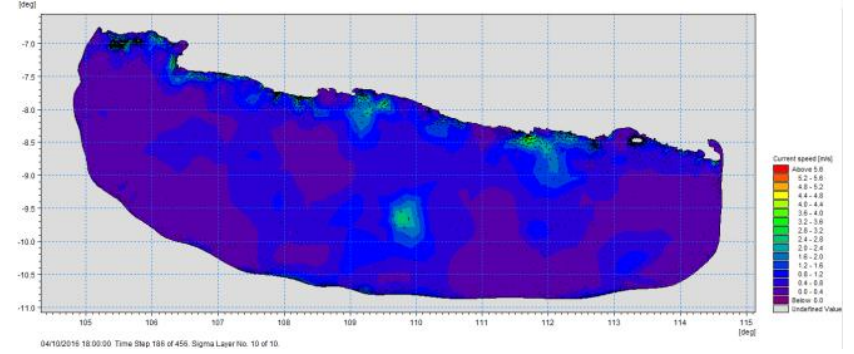

Gambar 5. Kondisi Arus Saat Pasang Tertinggi Pada Bulan Oktober 2016

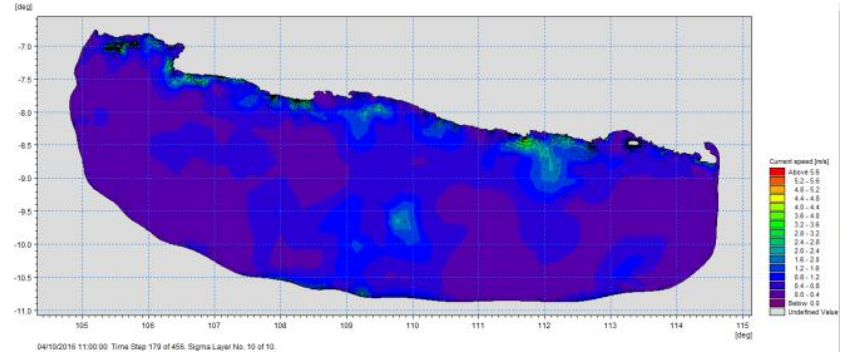

Gambar 6. Kondisi Arus Saat Surut Terendah Pada Bulan Oktober 2016

\section{Pemilihan Lokasi MCT}

Untuk menentukan lokasi MCT yang optimal, dilakukan dengan memasukkan 1428 titik yang memiliki nilai kedalaman antara $30 \mathrm{~m}$ sampai dengan $40 \mathrm{~m}$. Sebaran titik-titik tersebut dapat dilihat pada Gambar 7. Pemilihan kedalaman tersebut merupakan tempat rotor pada MCT yang terletak pada $1 / 3$ bagian atas kedalaman air (centroid) saat proses simulasi dilakukan.
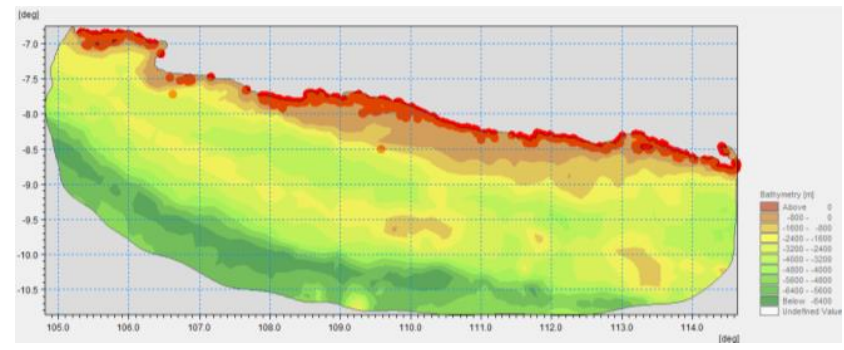

Gambar 7. Titik yang Memiliki Kedalaman $30 \mathrm{~m}$ sampai dengan $40 \mathrm{~m}$
Berdasarkan hasil pemodelan yang telah diperoleh, terdapat 124 titik yang memiliki nilai rata-rata kecepatan arus minimum $1,5 \mathrm{~m} / \mathrm{s}$. Hasil persebaran titik MCT yaitu, terdapat 22 titik persebaran lokasi MCT di bagian selatan Provinsi Banten, 32 titik di Provinsi Jawa Barat pada bagian selatan daerah Cipamingkis, Gardu, dan Ciawetali.

Hasil pemodelan juga menunjukkan bahwa di Provinsi Jawa Tengah terdapat 24 titik yang memiliki nilai rata-rata kecepatan arus minimum sebesar $1,5 \mathrm{~m} / \mathrm{s}$ yang terletak bagian selatan Kebumen.

Sedangkan lokasi yang memiliki potensi untuk dibangun MCT di Provinsi Jawa Timur tersebar di bagian selatan Tulung Agung, Trenggalek, Blitar, Pulau Sempu, Jember, dan Taman Nasional Alas Purwo. Gambar 8 menunjukkan sebaran dari lokasi yang memiliki potensi untuk dibangun MCT sebagai sumber energi alternatif yang terbarukan.

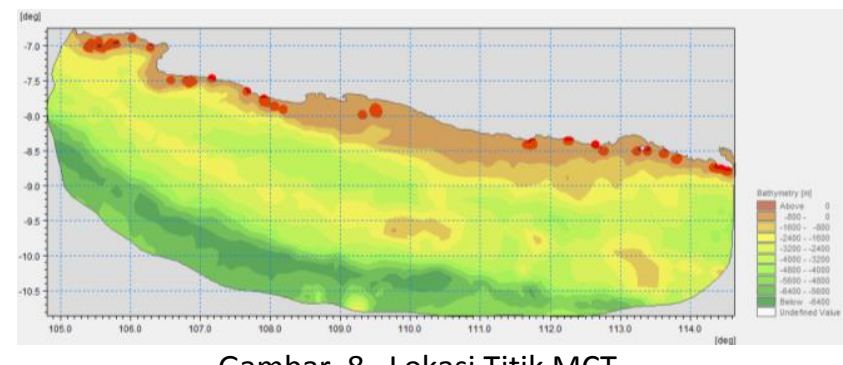
Gambar 8. Lokasi Titik MCT

\section{Analisa Estimasi Energi MCT}

Berdasarkan hasil analisis lokasi yang memiliki potensi untuk dibangun $M C T$, selanjutnya $d$ estimasi energi yang dihasilkan untuk setiap MCT. Estimasi energi yang dihasilkan dihitung berdasarkan MCT dengan rotor ganda dengan ukuran diameter rotor $(16 \mathrm{~m}, 18 \mathrm{~m}$, dan $20 \mathrm{~m})$ yang berputar selama 24 jam.

Nilai koefisien daya mengacu pada penelitian Fraenkl (1999) $(C p=0,35)$. Perhitungan estimasi energi yang dihasilkan pada Bulan Maret ditunjukkan pada Tabel 1 dan perhitungan estimasi energi yang dihasilkan pada bulan Oktober ditunjukkan pada Tabel 2 berikut. 
Tabel 1 Estimasi Energi Bulan Maret 2016

\begin{tabular}{lccc}
\hline \multicolumn{1}{c}{$\begin{array}{l}\text { Diameter } \\
\text { Rotor }(\mathrm{m})\end{array}$} & $\mathbf{1 6}$ & $\mathbf{1 8}$ & $\mathbf{2 0}$ \\
\hline $\begin{array}{l}\text { Energi Total } \\
\text { (kW/Hari) }\end{array}$ & 53,174 & 116,900 & 61,731 \\
$\begin{array}{l}\text { Energi Total } \\
(\mathrm{kW} / 15 \text { Hari) }\end{array}$ & 19142,742 & 42084,166 & 22223,026 \\
$\begin{array}{l}\text { Energi Rata- } \\
\text { rata per Bulan } \\
(\mathrm{MW})\end{array}$ & 38,285 & 84,168 & 44,446 \\
\hline
\end{tabular}

Tabel 2 Estimasi Energi Bulan Oktober 2016

\begin{tabular}{lccc}
\multicolumn{1}{c}{$\begin{array}{l}\text { Diameter } \\
\text { Rotor }(\mathbf{m})\end{array}$} & $\mathbf{1 6}$ & $\mathbf{1 8}$ & $\mathbf{2 0}$ \\
\hline $\begin{array}{l}\text { Energi Total } \\
\text { (kW/Hari) }\end{array}$ & 52,458 & 100,936 & 68,017 \\
$\begin{array}{l}\text { Energi Total } \\
\text { (kW/15 Hari) }\end{array}$ & 18884,791 & 36337,053 & 24485,972 \\
$\begin{array}{l}\text { Energi Rata- } \\
\text { rata per Bulan } \\
(\mathrm{MW})\end{array}$ & 37,770 & 72,674 & 48,972 \\
\hline
\end{tabular}

\section{KESIMPULAN}

Berdasarkan penelitian ini, pola arus bulan Maret saat pasang tertinggi memiliki kecepatan maksimum sebesar $5,881 \mathrm{~m} / \mathrm{s}$ sedangkan kecepatan arus bulan Oktober saat pasang tertinggi sebesar $5,679 \mathrm{~m} / \mathrm{s}$.

Terdapat 124 titik berpotensi yang memiliki nilai kecepatan arus minimal $1,5 \mathrm{~m} / \mathrm{s}$ untuk pembangunan MCT. 22 titik persebaran lokasi MCT terletak di bagian selatan Provinsi Banten, 32 titik di Provinsi Jawa Barat pada bagian selatan daerah Cipamingkis, Gardu dan Ciawetali, 24 titik di Provinsi Jawa Tengah yang terletak pada bagian selatan Kebumen, serta 46 titik di Provinsi Jawa Timur tersebar di bagian selatan Tulung Agung, Trenggalek, Blitar, Pulau Sempu, Jember dan Taman Nasional Alas Purwo
Estimasi energi yang dihasilkan turbin dengan rotor ganda dihitung berdasarkan ukuran diameter rotor serta nilai kedalaman lokasi turbin. Pada bulan Maret menghasilkan energi listrik sebesar 166,900 MWh sedangkan pada bulan Oktober 159,416 MWh.

\section{DAFTAR PUSTAKA}

ESDM. 2005. Diversifikasi Energi. "Energi Kelautan sebagai Alternatif Baru". DESDM. Jakarta: Seminar Pembangunan Ekonomi Kemaritiman.

Fraenkel, P., 1999. Power from Marine Currents, Marine Current Turbines Ltd.

Lubis, Saut Maruli, 2006. Oseanografi Indonesia. Program Studi Oseanografi. ITB: Bandung

Peraturan Presiden Republik Indonesia Nomor 5. 2006. Tentang Kebijakan Energi Nasional. Jakarta: Presiden Republik Indonesia

Undang Undang Nomor 17. 2007. Tentang Rencana Jangka Panjang Nasional (RPJPN). Jakarta : Rapublik Indonesia. 